\title{
ニボルマブ治療後に増悪した再発・転移性頭頸部扁平上皮癌に 対する救済化学療法の効果
}

\author{
花牟 禮豊林多聞 \\ 高木 実 伊東小都子
}

\begin{abstract}
要 旨
再発・遠隔転移性頭頸部癌に対して，免疫チェックポイント阻害薬であるニボルマブが承認されたが，従来の抗 癌剤や分子標的治療薬とは異なる反応や治療効果が示されている。先に承認された非小細胞肺癌においては免疫 チェックポイント阻害薬投与後の救済化学療法の有効性が高いことが示されている。今回，後方視的にニボルマブ 投与を行った再発・転移性頭頸部扁平上皮癌の 12 症例を検討し, その中で病勢が進行し後治療として救済化学療 法を行った 5 症例についてさらに詳細に検討した。救済化学療法は, タキサン系薬剤を含むレジメン（60\%）とプ ラチナ系薬剤を含むレジメン $(40 \%)$ を使用した。ニボルマブの奏効率は $16.7 \%$, 病勢制御率は $33.3 \%$ あっった。 一方， ニボルマブ後の救済化学療法の奏効率は $40 \%$, 病勢制御率は $80 \%$ であった。ニボルマブ治療により, 救済 化学療法の感受性が高まり有効性が期待できる可能性が示唆された。
\end{abstract}

キーワード : ニボルマブ, 再発・転移性頭頸部扁平上皮癌, 救済化学療法

Response to salvage chemotherapy after progression on nivolumab in patients with recurrent/metastatic head and neck squamous cell carcinoma:

Yutaka Hanamure, Tamon Hayashi, Minoru Takaki and Kotoko Ito

Department of Otolaryngology, Kagoshima City Hospital, Kagoshima

\begin{abstract}
Summary
Nivolumab has shown efficacy in patients with recurrent/metastatic head and neck squamous cell carcinoma (RM-HNSCC). Recent data suggest increased response rate to salvage chemotherapy after exposure to immune checkpoint inhibitors in advanced non-small cell lung carcinoma. We evaluated responses to salvage chemotherapy in RM-HNSCC patients who have progressed on nivolumab. A retrospective study was conducted at Kagoshima City Hospital. From May 2017 to February 2018, 12 patients were treated with nivolumab for RM-HNSCC and 5 patients whose diseases have progressed on nivolumab were received salvage chemotherapy. The overall response rate to nivolumab was $16.7 \%$ and the disease control rate was $33.3 \%$. Salvage chemotherapy included taxane-based regimen $(60 \%)$ and platinum-based regimen $(40 \%)$. The overall response rate to salvage chemotherapy was $40 \%$ and the disease control rate was $80 \%$. This suggests that nivolumab could make tumor more vulnerable to subsequent chemotherapy in RM-HNSCC patients.
\end{abstract}

Key words : Nivolumab, Recurrent/metastatic head and neck squamous cell carcinoma, Salvage chemotherapy

[Received Jul. 29, 2018, Accepted Feb. 15, 2019]

はじめに

再発または遠隔転移を有する頭頸部癌に対して，免疫 チェックポイント阻害薬であるニボルマブが承認された1)。 頭頸部癌治療の選択肢が増えその効果が期待されている

鹿児島市立病院耳鼻咽喉科

[平成 30 年 7 月 29 日受付, 平成 31 年 2 月 15 日受理]
が, 従来の抗癌剤や分子標的治療薬とは異なる反応や治療 効果が示されている。偽増殖 (Pseudoprogression) や過 増殖（Hyperprogression）を示す例があること 2,3)，また， 奏効例では長期に効果が持続することや, 不変例において も長期間, 腫瘍の増悪が押さえられることが報告されてい

別刷請求先： $=$ 890-8760 鹿児島市上荒田町 37-1 鹿児島市立病院耳鼻咽喉科

花牟禮 豊 
る。さらに，先に承認された非小細胞肺癌においては免疫 チェックポイント阻害薬投与後の救済化学療法の有効性が 高いことが示唆されている4,5)。

今回, ニボルマブによる治療を行った再発・転移性頭頸 部扁平上皮癌の症例を検討し, その中で病勢が進行し後治 療として救済化学療法を行った症例についてさらに詳細に 検討したので報告する。

\section{対象と方法}

鹿児島市立病院耳鼻咽喉科において 2017 年 5 月から 2018 年 2 月までにニボルマブ投与を行った再発・転移性 頭頸部扁平上皮癌患者 12 症例を対象とした。レトロスペ クティブに腫瘍径変化率, 総合効果, 奏効率, 病勢制御 率，生存期間などについて検討した。また，ニボルマブ治 療での進行例については, 化学療法の追加 (救済化学療法) が可能であった症例について, 同様に化学療法の治療効果 について検討した。治療効果判定には Response Evaluation Criteria in Solid Tumors（RECIST ver.1.1）を用いた。 なお, 本研究については院内 IRB にて承認を得て行った （承認No. 2018-09）。

\section{結 果}

対象症例は, 口腔癌 2 例, 上咽頭癌 2 例, 中咽頭癌 1 例, 下咽頭癌 5 例, 上顎癌 1 例, 耳下腺癌 1 例の計 12 例であっ た。局所再発が 10 例，遠隔転移が 3 例であり，1 例は局 所再発と遠隔転移の合併を認めた。ニボルマブ投与以前に 複数の化学療法行われており, そのレジメン数は, 平均
2.4 (範囲 : 2 3) であった。シスプラチン, ドセタキセ ル，5-Fu，パクリタキセル，セツキシマブを組み合わせ た複数のレジメン（TPF, FP+セツキシマブ，セッキシ マブ単独，パクリタキセル単独，シスプラチン単独）の使 用歴があり，1例（症例 10）を除き 11 例はセツキシマブ の使用歴があった。ニボルマブの投与回数は中央值 6 （範 囲：2２4）であった。ニボルマブによる総合効果は，完 全奏効 (CR) 1 例, 部分奏効 (PR) 1 例, 安定 (SD) 2 例, 進行（PD） 8 例であり，奏効率は $16.7 \%$ であった。病勢 制御率は $33.3 \%$ であり，ニボルマブ療法開始後の生存期間 は，現在生存中の 7 例を含めて中央值 30 週（範囲 : 7 〜 60)であった（表 1$) 。$

ニボルマブ単独療法にて PDであった 8 症例の中で 5 例に 後治療として化学療法 (救済化学療法)の追加が可能であっ た。救済化学療法は, PTX + Cmab 療法（パクリタキセル $80 \mathrm{mg} / \mathrm{m}^{2}$, セツキシマブ $250 \mathrm{mg} / \mathrm{m}^{2}$, 毎週) 2 例, DTX 療法 (ドセタキセル $60 \mathrm{mg} / \mathrm{m}^{2}, 3$ 週間毎) 1 例, $\mathrm{FP}+\mathrm{Cmab}$ 療法 (5-Fu 1,000mg/m² day1-4, CDDP $100 \mathrm{mg} / \mathrm{m}^{2}$ day 1,3 週間 毎, セツキシマブ初回 $400 \mathrm{mg} / \mathrm{m}^{2}, 2$ 回目以降 $250 \mathrm{mg} / \mathrm{m}^{2}$, 毎週）２例であった。救済化学療法を開始後，腫瘍は縮小 傾向を示す症例が多く（図 1), 最良総合効果は, CR 0 例, PR 2 例, SD 2 例, PD 1 例であり, 奏効率 $40 \%$, 病勢制 御率は $80 \%$ であった。CT 画像での標的病変の評価が可能 であった 4 例の中では, 腫瘍径最大変化率が-78.9\%に達 する症例もあった（図 2)。また, 救済化学療法症例の二 ボルマブ開始からの生存期間は，中央值 54 週（範囲：19 〜 60）であった（表 1）。2018 年 7 月現在， 5 例中 3 例は

表 1

\begin{tabular}{|c|c|c|c|c|c|c|c|c|c|c|c|c|c|}
\hline \multirow[b]{2}{*}{ 症 } & \multirow[b]{2}{*}{ 病名 } & \multirow[b]{2}{*}{ 年齢* } & \multirow[b]{2}{*}{ 性 } & \multirow[b]{2}{*}{$\begin{array}{l}\text { TNM 分類 } \\
\text { (治療開始時) }\end{array}$} & \multicolumn{3}{|c|}{ ニボルマブ投与前 } & \multicolumn{2}{|c|}{ ニボルマブ療法 } & \multicolumn{2}{|c|}{ 救済化学療法 } & \multirow{2}{*}{$\begin{array}{l}\text { 生存 } \\
\text { 期間 } \\
\text { (週)** }\end{array}$} & \multirow[b]{2}{*}{ 予後 } \\
\hline & & & & & 治療経過 & レジメン & $\begin{array}{c}\text { 再発転移 } \\
\text { 部位 }\end{array}$ & $\begin{array}{l}\text { 投与 } \\
\text { 回数 }\end{array}$ & $\begin{array}{l}\text { 総合 } \\
\text { 効果 }\end{array}$ & レジメン & $\begin{array}{c}\text { 最良総合 } \\
\text { 効果 }\end{array}$ & & \\
\hline 1 & 中咽頭癌 & 68 & 女 & T3N2cM0 & ICT, BRT, CT & $\mathrm{PTX}+\mathrm{Cmab}$ & 局所 & 5 & $\mathrm{PD}$ & $\mathrm{PTX}+\mathrm{Cmab}$ & $\mathrm{PD}$ & 19 & DOD \\
\hline 2 & 下咽頭癌 & 63 & 男 & T4bN2cM0 & ICT, CRT, CT & $\mathrm{FP}+\mathrm{Cmab}$ & 局所 & 12 & $\mathrm{PD}$ & DTX & $\mathrm{SD}$ & 60 & 担癌生存 \\
\hline 3 & 上咽頭癌 & 62 & 男 & T2N1M0 & BRT, CT & TPF & 咽頭後 LN & 24 & $\mathrm{CR}$ & - & - & 58 & 生存 \\
\hline 4 & 口腔癌 & 74 & 女 & T4aN0M0 & ICT, OP, CT & $\mathrm{FP}+\mathrm{Cmab}$ & 局所 & 4 & $\mathrm{PD}$ & $\mathrm{PTX}+\mathrm{Cmab}$ & PR & 56 & 担癌生存 \\
\hline 5 & 口腔癌 & 66 & 女 & T3N2bM0 & OP, CT, BRT & TPF & 局所 & 10 & PR & - & - & 55 & 担癌生存 \\
\hline 6 & 下咽頭癌 & 65 & 男 & T4aN2bM0 & ICT, BRT, CT & $\mathrm{PTX}+\mathrm{Cmab}$ & 局所 & 4 & $\mathrm{PD}$ & $\mathrm{FP}+\mathrm{Cmab}$ & PR & 54 & 担癌生存 \\
\hline 7 & 下咽頭癌 & 49 & 男 & T4aN2bM0 & ICT, BRT, CT & $\mathrm{FP}+\mathrm{Cmab}$ & 局所 & 3 & $\mathrm{PD}$ & - & - & 7 & DOD \\
\hline 8 & 耳下腺癌 & 65 & 男 & T4bN2bM0 & 粒子線, CT & $\begin{array}{l}\mathrm{FP}+\mathrm{Cmab} \\
\mathrm{PTX}+\mathrm{Cmab}\end{array}$ & 遠隔（肺） & 2 & $\mathrm{PD}$ & - & - & 12 & DOD \\
\hline 9 & 下咽頭癌 & 69 & 男 & T4bN2bM0 & ICT, BRT, CT & $\mathrm{FP}+\mathrm{Cmab}$ & 局所 & 6 & $\mathrm{PD}$ & - & - & 11 & DOD \\
\hline 10 & 上顎癌 & 74 & 女 & T3N2bM0 & ICT, OP, CRT & $\begin{array}{c}\text { CRT } \\
\text { (CDDP) }\end{array}$ & $\begin{array}{c}\text { 局所 + 遠隔 } \\
\text { (肺, 肝) }\end{array}$ & 6 & $\mathrm{PD}$ & $\mathrm{FP}+\mathrm{Cmab}$ & $\mathrm{SD}$ & 30 & DOD \\
\hline 11 & 下咽頭癌 & 73 & 男 & T4aN2bM0 & OP, CRT, CT & $\mathrm{FP}+\mathrm{Cmab}$ & 遠隔（肺） & 11 & SD & - & - & 30 & 担癌生存 \\
\hline 12 & 上咽頭癌 & 65 & 女 & T4N1M0 & CRT, CT & $\mathrm{FP}+\mathrm{Cmab}$ & 咽頭後 LN & 7 & SD & - & - & 21 & 担癌生存 \\
\hline
\end{tabular}

ICT : 導入化学療法, BRT : セツキシマブ併用放射線療法, CRT : 化学放射線療法, OP : 手術, CT : 化学療法

$\mathrm{CR}$ : 完全奏効, $\mathrm{PR}$ : 部分奏効, $\mathrm{SD}$ : 安定, $\mathrm{PD}$ : 進行, $\mathrm{DOD}$ : 原病死

*: ニボルマブ投与開始時の年齢, **: ニボルマブ開始後の生存期間 


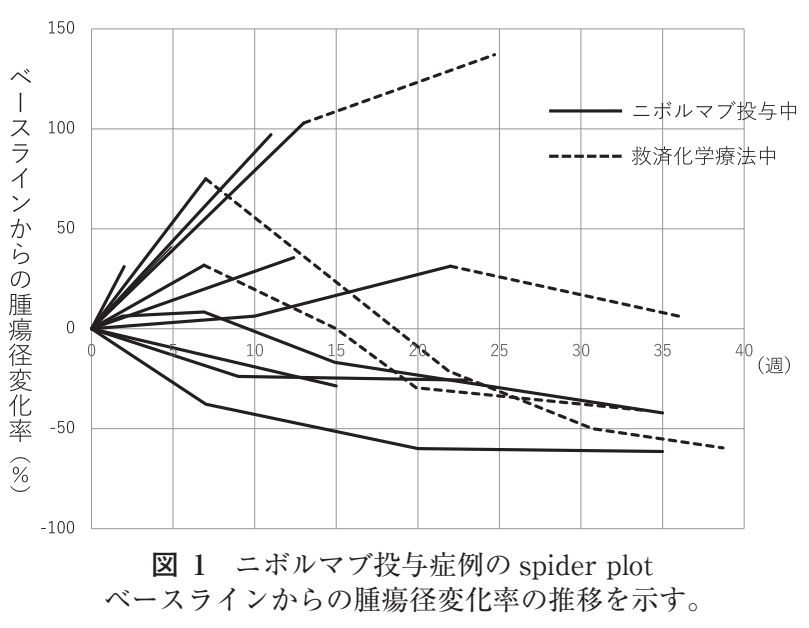

生存中である。特に著明な効果が得られた 1 例（症例 4) を提示する。

\section{症例}

症例：74 歳 女性（表 1 の症例 4)。

主訴：右下顎歯肉違和感。

既往歴：13 年前 右舌縁癌にて舌部分切除術。

6 年前 右口腔底癌にて手術し術後放射線治療 を施行。

現病歴 :

$\mathrm{X}-2$ 年（Xはニボルマブ投与開始時点）右下顈歯肉違 和感が出現した。

$\mathrm{X}-17 \mathrm{M}$ (X-17 ケ月) 近医歯科を受診し当科を紹介された。 経過 :

$\mathrm{X}-16 \mathrm{M}$ 右下顎歯肉癌, T4aN0M0, Stage IV A の臨床診 断にて, 右下顎歯肉悪性腫瘍手術（右下顎歯肉煩粘膜口腔 底切除, 下顎骨区域切除術), 下顎口腔底再建術（下顎再 建用チタンプレート，腹直筋皮弁術）を施行した。

$\mathrm{X}-8 \mathrm{M}$ （術後 8 ケ月）口腔底正中再発および左頸部リン パ節転移を認めた。全身化学療法の一次治療として FP+ $\mathrm{Cmab}$ 療 法 (5-Fu 1,000mg/ $\mathrm{m}^{2}$ day1-4, CDDP $100 \mathrm{mg} / \mathrm{m}^{2}$ day 1, 3 週間毎, セツキシマブ初回 $400 \mathrm{mg} / \mathrm{m}^{2}, 2$ 回目以 降 $250 \mathrm{mg} / \mathrm{m}^{2}$, 毎週) を開始した。 $\mathrm{FP}+\mathrm{Cmab}$ 療法 2 コー スを施行したが，骨髄抑制が遷延化するため， Cmabのみ を継続し，PR を維持していた。

$\mathrm{X}+0 \mathrm{M}$ 口腔底正中および左頸部リンパ節再発の増大を 認めた。最終のシスプラチン投与後 6 ヶ月以内の再増大で あり, プラチナ抵抗性と判断し, ニボルマブ単独療法を開 始した。

$\mathrm{X}+2 \mathrm{M}$ ニボルマブ開始 2 ヶ月後にオトガイ下部と左頸 部リンパ節転移の急速な増大があり, 疼痛の増強および與燕 下障害が出現した。ニボルマブ投与を中止し, 三次治療 (救済化学療法) として PTX + Cmab 療法（パクリタキセ ル $80 \mathrm{mg} / \mathrm{m}^{2}$, セツキシマブ $250 \mathrm{mg} / \mathrm{m}^{2}$, 毎週) を開始した。 $\mathrm{X}+3 \mathrm{M}$ 骨髄抑制のため化学療法を 2 投 1 休に変更した。 $\mathrm{X}+5 \mathrm{M}$ ざ瘡様皮疹および下腿紅色丘疹, 膿疮が増強し,

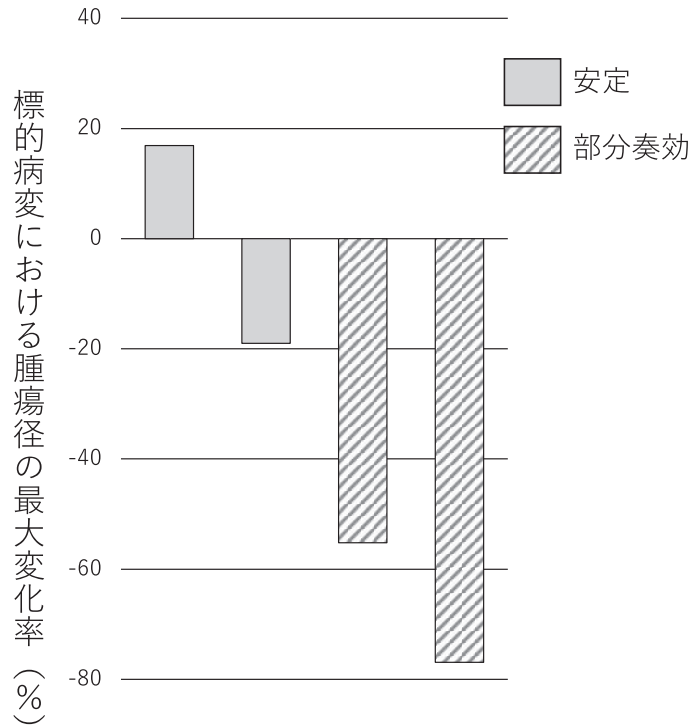

图 2 二ボルマブ療法後の救済化学療法の効果 ニボルマブ単独療法にて PD であり, CT 画像での標的病変 の評価が可能であった 4 例の救済化学療法の効果（標的病変 における腫瘍径の最大変化率）を示す。

皮膚症状の増強（Grade 3）を認めたため化学療法を 1 ケ 月間休止した。

$\mathrm{X}+6 \mathrm{M}$ 化学療法 (PTX + Cmab 療法, PTX を $80 \%$ 量 に減量）を再開した。

$\mathrm{X}+7 \mathrm{M}$ 気管支肺炎を生じ化学療法を 6 週間休止した。 下顎再建のチタンプレートがオトガイ部皮膚から一部露出 した。

$\mathrm{X}+8 \mathrm{M}$ 化学療法 (PTX + Cmab 療法) を PTX 80\%量, 2 週毎投与に変更し，再開した。腫瘍は著明に縮小し $\mathrm{PR}$ を維持している（図 3)。

\section{考察}

再発・遠隔転移を来した頭頸部癌に対する初回化学療法 として, 現在, CDDP+5-Fu にセッキシマブを併用する EXTREME レジメン6) $(\mathrm{FP}+\mathrm{Cmab}$ 療法 $)$ が頭頸部癌診療 ガイドラインにても推奨され標準治療となっている7)。初 回化学療法にて効果が得られない場合, 二次治療 $\left(2^{\text {nd }}\right.$ line）として PTX + Cmab 療法や DTX 療法が治療選択肢 として位置づけられている。CheckMate-141 試験にて免 疫チェックポイント阻害薬であるニボルマブの有効性・安 全性が示され ${ }^{11}, 2017$ 年 3 月に頭頸部癌へ適応拡大となり, ニボルマブが $2^{\text {nd }}$ lineの治療として普及しつつある。ニボ ルマブは, 従来の抗癌剤や分子標的治療薬とは異なる反応 や治療効果が示されており, 生存が長期にわたり, 全生存 期間 (OS) の延長や長期間の効果持続が期待されている。 われわれの症例でも再発・遠隔転移例にもかかわらず，ま た, ニボルマブにて SD P PD 症例においてもニボルマブ 投与開始後 1 年以上の長期生存例が複数確認された。

がんに対しては免疫応答が機能しており, 臨床的にわ 

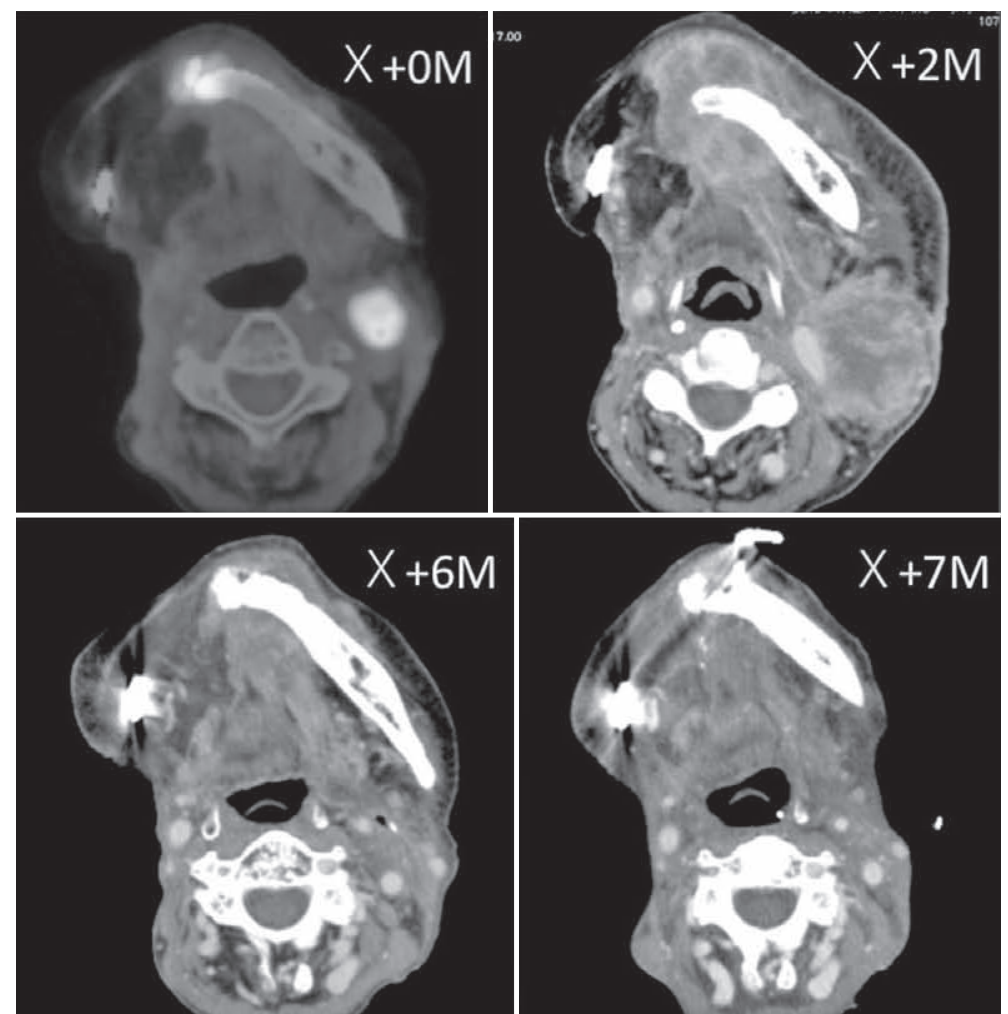

図 3 症例 4 の画像所見

$\mathrm{X}+0 \mathrm{M}$ : ニボルマブ開始前の $\mathrm{PET} / \mathrm{CT}$ (術後 1 年 4 ケ月), $\mathrm{X}+2 \mathrm{M}:$ ニボ ルマブ投与 4 回目の CT (救済化学療法前), $\mathrm{X}+6 \mathrm{M}$ : 救済化学療法 4 ヶ月 目の $\mathrm{CT}, \mathrm{X}+7 \mathrm{M}$ : 救済化学療法 5 ケ月目の CT

れわれが遭遇する癌患者はすでに免疫からの逃避相にあ り, 何らかの免疫抑制, 免疫逃避機構を獲得していること が予想されている8)。ニボルマブの投与により，がん免疫 微小環境が变化し, 次治療の奏効率を高め, その結果, 予 後延長の可能性が指摘されている。非小細胞肺癌におい て, 免疫チェックポイント阻害薬投与後に使用した殺細胞 性抗癌剤による化学療法の有効性が高いことが報告され ており ${ }^{4,5)}$, 胃癌においても同様のことが示唆されている。 CheckMate-141 試験のサブ解析にて, 日本人集団の OS が 良かったことが指摘され，その理由に日本人集団の多くが 後治療の化学療法を受けていたことが挙げられている ${ }^{9)}$

今回の症例数は少ないものの, ニボルマブ療法の奏効率 は $16.7 \%$ であるが, ニボルマブ PD 後に追加された救済化 学療法の奏効率は $40 \%$ と高い効果が得られた。ニボルマ ブ療法後に救済化学療法の有効性が期待できる可能性が示 唆される。今後, ニボルマブ投与前の化学療法とニボルマ ブ後の救済化学療法について, 症例を集積した上で奏効率 等の比較検討が望まれる。

今回提示した一症例では, ニボルマブ後に使用した化学 療法 $(\mathrm{PTX}+\mathrm{Cmab}$ 療法) にて, Grade 3 の皮膚症状が出 現した。セツキシマブによる有害事象と考えられるが, 本 症例はニボルマブ使用前にもセツキシマブ使用歴があり, その際は，このように強い皮膚症状はなく，ニボルマブ使 用後にセツキシマブに対する反応性が増強したことがうか
がわれる。ニボルマブ投与前に行った化学療法では効果が 無かったのに, ニボルマブ後に行った化学療法では反応性 が増し, 効果を示す症例があることを示している。その機 序は不明であるが, PD-1 阻害薬は 2 ケ月以上にわたりリ ンパ球の PD-1 を占拠することが報告されており ${ }^{10)}$, 二ボ ルマブ後に引き続き化学療法を行うことにより殺細胞性の 化学療法薬とニボルマブの相加作用, 相乗作用を示した可 能性も考えられる。

従来の化学療法は, 癌細胞の細胞増殖抑制や細胞障害 性によってその効果がもたらされていると考えられてき た。しかし，近年になって長期臨床効果には T 細胞に代 表される免疫細胞が関与していることが明らかになってき ている。化学療法薬は, 癌細胞のみでなく, 免疫担当細胞 や免疫抑制細胞に直接働きかけ，抗腫瘍効果に影響を及ぼ すことが判明している。シスプラチンは, 腫瘍特異的抗原 の発現上昇とそれに伴う CTL（細胞障害性 T 細胞）の誘 導促進が報告されている ${ }^{11)}$ 。パクリタキセルは, 癌細胞上 の MHC（主要組織適合遺伝子複合体）Class I 分子の発現 を交進し抗原性を高めることや, 樹状細胞に直接的に作用 し, $\mathrm{T}$ 細胞への抗原提示能を立進することが示されてい

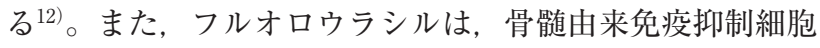
(myeloid-derived suppressor cells ; MDSCs) のアポトー シスを選択的に誘導し，抗腫瘍効果を増大させることも明 らかにされている13)。これらの殺細胞性化学療法薬の前に, 
ニボルマブを投与することにより，癌免疫微小環境が変化 し, 次の化学療法薬による免疫担当細胞や免疫抑制細胞へ の作用が影響を受け，本来の殺細胞効果との相互作用によ

り効果が高まる可能性も考えられ大変興味深い点である。 複数の薬剂を組み合わせる複合的免疫療法が考えられ ており, 免疫チェックポイント阻害薬を先に投与するこ とにより体内の免疫環境が変化し, 他の治療法に切り替 えても, その変化した免疫環境が維持されている可能性が ある。また, 単剂の免疫療法が無効でも, 免疫サイクル ${ }^{8)}$ を考慮すると複数の免疫療法薬あるいは免疫療法薬と化学 療法薬を組み合わせることで有効性が示される可能性があ り,さらに, 免疫療法薬に従来の抗癌剂や分子標的治療薬 との順序を考慮した治療戦略も期待される。頭頸部癌にお いても, 今後の治療戦略が大きく変化する可能性が示唆さ れる。

$$
\text { まとめ }
$$

ニボルマブを投与した再発・遠隔転移性頭頸部扁平上皮 癌患者において, PD 後の救済化学療法により腫瘍縮小が 高率に認められた。ニボルマブ治療後に行う救済化学療法 において有効性が期待できる症例があることが示唆された。

本論文について申告すべき利益相反は有しない。

本論文の要旨は第 42 回日本頭頸部癌学会（2018 年 6 月）にて 発表した。

\section{文献}

1) Ferris R.L., Blumenschein G. Jr., Fayette J., et al: Nivolumab for Recurrent Squamous-Cell Carcinoma of the Head and Neck. N Engl J Med 375 : 1856-1867, 2016

2) Champiat S., Dercle L., Ammari S., et al: Hyperprogressive Disease Is a New Pattern of Progression in Cancer Patients Treated by Anti-PD-1/PD-L1. Clin Cancer Res $23: 1920-$
1928, 2017

3) Saâda-Bouzid E., Defaucheux C., Karabajakian A., et al: Hyperprogression during anti-PD-1/PD-L1 therapy in patients with recurrent and/or metastatic head and neck squamous cell carcinoma. Ann Oncol 28 : 1605-1611, 2017

4) Schvartsman G., Peng S.A., Bis G., et al: Response rates to single-agent chemotherapy after exposure to immune checkpoint inhibitors in advanced non-small cell lung cancer. Lung Cancer $112:$ 90-95, 2017

5) Park S.E., Lee S.H., Ahn J.S., et al: Increased Response Rates to Salvage Chemotherapy Administered after PD-1/PD-L1 Inhibitors in Patients with Non-Small Cell Lung Cancer. J Thorac Oncol 13: 106-111, 2018

6) Vermorken J.S., Mesia R., Rivera F., et al: Platinum-based chemotherapy plus cetuximab in head and neck cancer. N Engl J Med 359 : 1116-1127, 2008

7）丹生健一：再発・転移頭頸部癌に対する初回化学療法におい てセツキシマブの併用は有用か？ 頭頸部癌診療ガイドライ ン 2018 年版, 日本頭頸部癌学会編, 金原出版, 東京, 2017, pp152-153.

8) Chen D.S., Mellman I.: Oncology Meets Immunology: The Cancer-Immunity Cycle. Immunity $39: 1-10,2013$

9) Kiyota N., Hasegawa Y., Takahashi S., et al: A randomized, open-label, Phase III clinical trial of nivolumab vs. therapy of investigator's choice in recurrent squamous cell carcinoma of the head and neck: A subanalysis of Asian patients versus the global population in checkmate 141. Oral Oncology $73: 138-146,2017$

10) Brahmer J.R., Drake C.G., Wollner I., et al: Phase I study of single-agent anti-programmed death-1 (MDX-1106) in refractory solid tumors: safety, clinical activity, pharmacodynamics, and immunologic correlates. J Clin Oncol 28 : 3167-3175, 2010

11) Jackaman C., Majewski D., Fox S.A., et al: Chemotherapy broadens the range of tumor antigens seen by cytotoxic CD8 (+ ) T cells in vivo. Cancer Immunol Immunother $61: 2343-2356,2012$

12) Shurin G.V., Tourkova I.L., Kaneno R., et al: Chemotherapeutic agents in noncytotoxic concentrations increase antigen presentation by dendritic cells via an IL-12-dependent mechanism. J Immunol $183: 137-144,2009$

13) Vincent J., Mignot G., Chalmin F., et al: 5-Fluorouracil selectively kills tumor-associated myeloid-derived suppressor cells resulting in enhanced $\mathrm{T}$ cell-dependent antitumor immunity. Cancer Res $70: 3052-3061,2010$ 